\title{
Cessation of the pacifier sucking habit and self-correction of the anterior open bite in the primary dentition: case report
}

\author{
Interrupção do hábito de sucção de chupeta e autocorreção \\ da mordida aberta anterior na dentição \\ decídua: relato de casos
}

\author{
Gabriela Petri de BORTOLO1 (iD) https://orcid.org/0000-0002-3836-3822 \\ Lilian Citty SARMENTO² ID https://orcid.org/0000-0002-0409-1638 \\ Ana Paula Martins GOMES² iD https://orcid.org/0000-0002-1064-0322 \\ Ana Maria Martins GOMES² iD https://orcid.org/0000-0001-7869-248X \\ Maria Christina Thomé PACHECO² iD https://orcid.org/0000-0001-7576-2382 \\ Elâine Cristina Vargas DADALTO² iD http://orcid.org/0000-0002-1698-3326
}

\section{ABSTRACT}

Objective: To evaluate the effectiveness of play strategies to break the pacifier-sucking habit and induce self-correction of the anterior open bite in the primary dentition. Methods: Data collection took place at the Pediatric Dentistry clinic of a public education institution. Three children, aged between 3 and 4 years old, using a pacifier and presenting with a 2 to 5 mm anterior open bite, participated in the research. Pediatric dental guidance was imparted to educate the family and to provide play strategies for the child by means of an illustrated book about the pacifier fairy. Results: After the first consultation, two children quit their pacifier habit. Subsequent consultations were devoted to positive reinforcement and follow-up of the self-correction of the anterior open bite. The third child required four visits to stop the pacifier habit, but other habits persisted and the open bite was only corrected after intervention by a multidisciplinary team. Conclusion: After receiving orientation from the professionals, the parents/guardians cooperated in stimulating the child, and the play activities were effective in encouraging the child to stop sucking on the pacifier, permitting self-correction of the anterior open bite. Bottle feeding, tongue interposition and mouth breathing may hinder the spontaneous correction of the anterior open bite after the pacifier habit is abandoned, requiring multidisciplinary intervention.

Indexing terms: Pacifiers. Malocclusion. Child.

\footnotetext{
$\checkmark \nabla \nabla$
}

1 Universidade Federal do Espírito Santo, Residência Multiprofissional em Saúde, HUCAM/CCS. Av. Mal. Campos, 1468, Maruípe, 29047-105, Vitória, ES, Brasil. Correspondence to: GP de BORTOLO. E-mail: <gabrieladebortolo@gmail.com>.

2 Universidade Federal do Espírito Santo (UFES), Curso de Odontologia, Departamento de Clínica Odontológica. Vitória, ES, Brasil.

$\boldsymbol{\nabla} \boldsymbol{\nabla} \boldsymbol{\nabla}$

How to cite this article

Bortolo GP, Sarmento LC, Gomes APM, Gomes AMM, Pacheco MCT, Dadalto ECV. Cessation of the pacifier sucking habit and self-correction of the anterior open bite in the primary dentition: case report. RGO, Rev Gaúch Odontol. 2021;69:e20210060. http://dx.doi.org/10.1590/1981863720210006020200085 


\section{RESUMO}

Objetivo: Avaliar a eficácia de estratégias lúdicas para interrupção do hábito de sucção de chupeta e a autocorreção da mordida aberta anterior na dentição decídua. Métodos: A coleta dos dados ocorreu na clínica de Odontopediatria de uma instituição pública de ensino. Participaram 03 crianças, de 3-4 anos de idade, em uso de chupeta e apresentando mordida aberta anterior. Foi efetuada orientação para conscientização da família e estratégias lúdicas para a criança, com um livro ilustrado sobre a fada da chupeta. Resultados: Após primeiro atendimento, duas crianças interromperam o hábito de chupeta. As consultas seguintes foram para reforço positivo e acompanhamento da autocorreção da mordida aberta anterior. A terceira criança necessitou de quatro atendimentos para interromper o hábito da chupeta, porém outros hábitos persistiram e a correção da mordida aberta ocorreu após intervenções da equipe multidisciplinar. Conclusão: Após orientação profissional, os pais/responsáveis colaboraram para estimular a criança e os recursos lúdicos foram eficientes para incentivar a criança a interromper a sucção de chupeta, possibilitando autocorreção da mordida aberta anterior. Uso de mamadeira, interposição lingual e respiração bucal podem dificultar a correção espontânea desta má oclusão após abandono da chupeta, sendo necessária intervenção multidisciplinar.

Termos de indexação: Chupetas. Má Oclusão. Criança.

\section{INTRODUCTION}

Deleterious oral habits are significant factors in the establishment of changes in the craniofacial complex and the development of malocclusion in the primary dentition, particularly the habits of thumb-sucking and the use of pacifiers $[1,2]$. The prolonging of the non-nutritive sucking habit increases the risks and complications from these changes [3]. Malocclusions most commonly associated with the habit of sucking were anterior open bite and posterior crossbite [4].

The practice of using pacifiers is steeped in the culture [5]. Some parents understand that prolonging the habits may be prejudicial, but experience difficulty in trying to stop them as they may depend on the benefits that they ascribe to the use of pacifiers, such as the calming of the child, stopping the child from crying, distracting the child, as this is a common practice, not to mention convenient for the parents $[3,6]$.

The absence of breastfeeding or having been breastfed for a period of less than six months was associated with a four times greater probability of developing pacifier sucking than children who are breastfed for six months or longer [7]. In addition, these children were twice as likely to develop malocclusion by the age of six [8], particularly anterior open bite and posterior crossbite [9]. Even where the type of feeding was not directly associated with the development of malocclusion [10], it has been demonstrated that exclusive breastfeeding is associated with a protective effect and a reduced risk of acquiring non-nutritive sucking habits [10-12].

In children who were breastfed up until six months of age and who subsequently progressed to the bottle, the occurrence of orofacial changes was higher than in those who used beakers after ceasing to be breastfed [13]. The majority of children have presented with some form of deleterious oral habit, and sucking on a feeding bottle merits particular attention since it was reported in $81.8 \%$ of cases, and may be used exclusively or in conjunction with another habit, such as the sucking of a pacifier [14].

The presence of deleterious oral habits needs to be identified early on in order to encourage the cessation of the habit and enable the infant to enjoy a better quality of life, encouraging adequate conditions of feeding, breathing and talking, enhancing orofacial harmony and balance [15]. Extending the pacifier-sucking habit beyond three years of age leads to orofacial changes and loss of occlusion, demonstrating that motivational strategies should be employed in order to transmit knowledge of health education and make both children and adults aware of the rationalization behind the decision to make use of the pacifier [6].

Anterior open bite is self-correctable in the primary dentition as long as the sucking habit is discontinued, recommended to take place around 2 years of age $[2,16]$ or at least by the age of three $[3,6]$. Several authors have shown that self-correction can occur in the transition from the primary to the mixed dentition when the non-nutritive sucking habit is abandoned prior to six years of age, in other words prior to the eruption of the permanent upper incisors, as long as the child exhibits a favorable growth pattern $[17,18]$. However, this tendency quickly diminishes when the child is already in the phase of the mixed or permanent dentition [2].

The prolonging of the child's non-nutritive sucking habits during the mixed dentition becomes a complicating 
factor that affects dental occlusion and may cause more severe changes in the stomatognathic system due to the imbalance of the forces that are naturally at work in the oral cavity $[2,19,20]$. Anterior open bite may recur when incorrectly diagnosed and when a multidisciplinary treatment plan has not been established, and is considered one of the most difficult malocclusions to treat [21]. Whenever necessary, multidisciplinary assistance is advocated to minimize any damage [4].

The playing of games that help to banish sucking habits is extremely important for the child's adherence and cooperation. Parents need to be well briefed and engaged in this process. It is important, as an initial strategy, to acquire data concerning the frequency, duration and intensity of the habit, to obtain the acquiescence of the child to give up the habit and whether the parents are aware of the resulting changes. Subsequently, the problem is presented to the child followed by a third stage in which the motivational resource is applied using play activities such as puppet stories, slide presentations, illustrations and photographs related to anterior open bite, as strategies for abandoning the habit. There is also a need for daily encouragement by the parents including praise, smiles and hugs when the child's behavior is consistent with the attempt to give up the habit $[17,22]$.

Given that professional guidance and the application of games is important in influencing the cessation of sucking habits and, accordingly, enabling selfcorrection of anterior open bite, it becomes important to address this content both from a scientific perspective, i.e. malocclusion, and a social perspective, as it is a low-maintenance, interceptive intervention, based on orientation and follow-up. In view of the above, the aim of the present study was to evaluate the efficacy of ludic strategies to stop the habit of pacifier sucking and for the self-correction of anterior open bite in the primary dentition.

\section{CASE REPORT}

Three children, aged between 3 and 4 years, took part in the study. They attended the Pediatric Dentistry clinic of a public education institution in the multidisciplinary residency program for child and adolescent healthcare, and presented with a persistent pacifier-sucking habit in the primary dentition. During anamnesis, the parents/ guardians provided data concerning the child's overall health, diet and the use of the pacifier. The observations obtained from these reports were noted to help interpret each case. The children were subjected to facial and intraoral examination, including the measurement of the anterior open bite (AOB).

The project design was submitted for the approval of the Research Ethics Committee at the Federal University of Espírito Santo (CAAE no. 24383119.5.0000.5060). The parents/guardians signed a "Free and Informed Consent Agreement" in compliance with National Health Council resolution 466/12.

The parents/guardians received guidance concerning the occlusal and myofunctional changes resulting from a protracted habit of using a pacifier, individualized in accordance with the changes observed in each child, and were made aware of the need for the cessation of the habit, though without any obligation to remove it. In this phase, photographs were shown of a child with $A O B$ and of the same child with normal occlusion after kicking the habit of sucking on a pacifier. They were shown to the adults and the children and then, using a mirror, the child would observe his/her own smile. The aim was to establish a comparative method for creating awareness and understanding of malocclusion and to demonstrate that the child's smile could improve after the habit is abandoned.

The child also received guidance using play strategies to encourage the spontaneous cessation of the use of the pacifier by showing them an illustrated book with the description of a story about the pacifier fairy. The aim was to encourage the child to try and kick the habit, by feeling encouraged and convinced that it was the child him/herself who made the best decision [23]. After the presentation of the ludic activities, an analysis was carried out of their understanding of these instructions. Periodic return appointments were scheduled to reinforce the instructions and where the parents/guardians were asked if the child was continuing to use the pacifier or if the frequency of sucking the pacifier had reduced, and about the child's adherence to the proposed method.

The three children were monitored in the Pediatric Dental clinic by the same professional. At each consultation, a new intraoral clinical examination was performed to measure the $A O B$ or to check for self-correction of the malocclusion. In persistent cases of open bite, the potential associated factors were evaluated including mouth 
breathing and tongue interposition. Two of these children, cases 1 and 2, presented with pacifier- and bottle-sucking as risk factors for the development of $\mathrm{AOB}$ and succeeded in self-correcting the malocclusion in a short period of time, while the child in case 3 , in addition to using the pacifier and bottle, presented with interposition and hypotonicity of the tongue as factors influencing the development and persistence of $\mathrm{AOB}$.

\section{Clinical case 1}

Female child aged 3 years and 7 months was instructed and monitored for 5 months. She was breastfed until four months old, in conjunction with the use of a feeding bottle from the moment she was born, and began the habit of sucking on the pacifier before she completed one month. The child's mother died and her principal caregiver was her maternal grandmother, who appeared to be interested and committed to the treatment.

The child presented with $5 \mathrm{~mm} A O B$ in the region of the central and lateral incisors, second primary molars with a straight profile on both sides, Class I left and right canine relationship, coinciding upper and lower midlines, presence of diastemas in the top and bottom arches, nose breathing, presence of lip sealing in the rest position and an overall satisfactory tooth condition.

Initially, she was subjected to three sessions dedicated to encouraging the cessation of the habit of sucking on the pacifier and the bottle, and reinforcement of the guidance. The first consultation was fundamental in educating and incentivizing the family and child concerning the need to abandon the habit. The subsequent sessions were dedicated to positive reinforcement, clarification of any doubts, supplementary instructions and an evaluation of the orofacial structure. Within four months, the child's $A O B$ had self-corrected, as can be seen in figure 1 below.

\section{Clinical Case 2}

Three-year-old female was instructed and monitored for 8 months. Born preterm, she still received breastmilk from time to time and used a bottle from five months, twice daily. She started using a pacifier before she was even one month old. Her principal caregiver is her mother, who appeared to be interested and committed to the treatment. The mother reported that the child was accustomed to sleeping with her mouth open.

The child presented with $4 \mathrm{~mm} A O B$ in the region of the central and lateral incisors, second primary molars with a straight profile on both sides, Class I left and right canine relationship, coinciding upper and lower midline, oronasal breathing, absence of lip sealing at rest, and overall satisfactory tooth condition.

She was subjected to five sessions dedicated to encouraging the cessation of the pacifier- and bottlesucking habits. The first consultation was effective in making the family and child aware and gaining their cooperation for the cessation of these habits. The subsequent sessions involved activities to clarify doubts, supplementary instruction and evaluation of the orofacial structures, with guidance on the awareness of the need for lip sealing. After seven months, the child's open bite had self-corrected (figure 2).

\section{Clinical Case 3}

Male child, aged 4 years and 3 months, was instructed and monitored for 10 months. In the anamnesis,

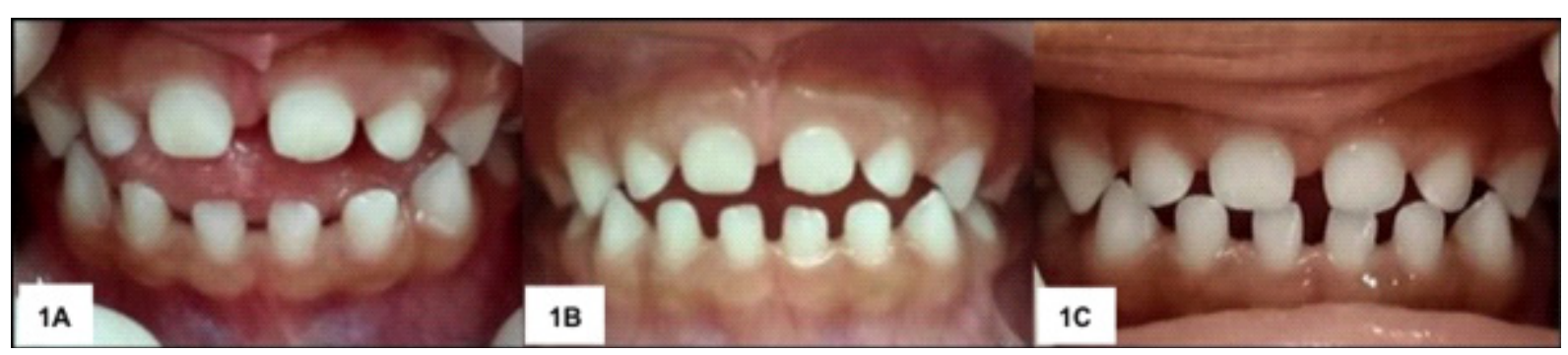

Figure 1. Evolution of spontaneous correction of anterior open bite (AOB) in Case 1. A) Initial appearance in a child aged 3 years and 7 months, using pacifier and bottle, with an $\mathrm{AOB}$ of $5 \mathrm{~mm}$. B) AOB viewed two months after abandoning the habits. C) Final evaluation of occlusion, showing self-correction of $A O B$ four months after abandoning the habits. 


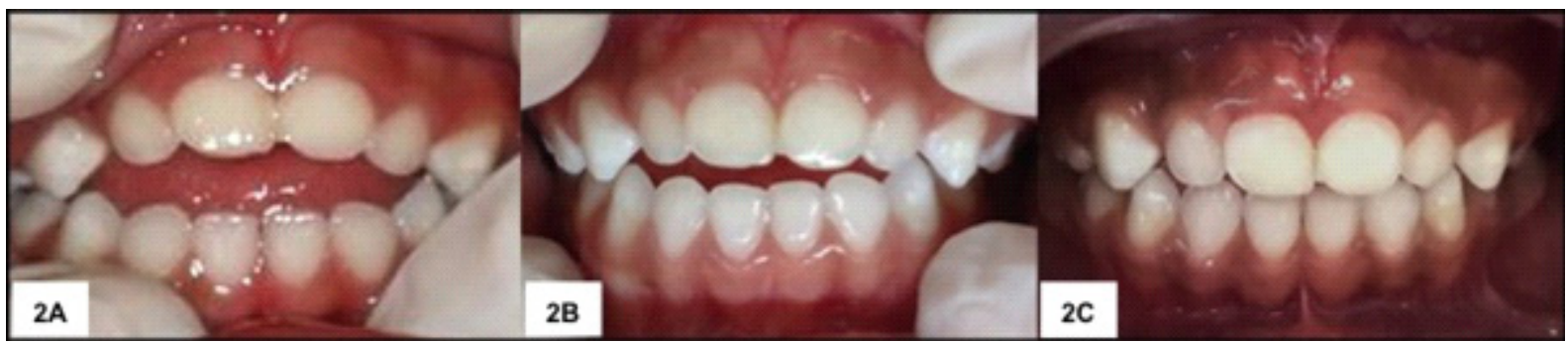

Figure 2. Evolution of spontaneous correction of anterior open bite (AOB) in Case 2. A) Initial appearance in a child aged 3, with pacifier and bottle-sucking habit; $\mathrm{AOB}$ of $5 \mathrm{~mm}$. B) $\mathrm{AOB}$ viewed five months after abandoning the habits. C) Final evaluation of occlusion, showing self-correction of $A O B$ seven months after abandoning the habits.

important information was highlighted including: absence of breastfeeding, use of feeding bottle since the first few days of life, amounting to four bottles daily and the pacifier habit began at two months. The parents and maternal grandmother were the main caregivers and demonstrated difficulty in complying with the instructions as supplied.

The child presented with lip sealing at rest, however, during the consultations, it was possible to identify other etiological factors for $\mathrm{AOB}$ such as interposition and hypotonicity of the tongue, an oronasal breathing pattern as well as phonetic impairment. The child presented with $2 \mathrm{~mm} \mathrm{AOB}$ in the region of the central and lateral incisors; $4 \mathrm{~mm}$ overjet; second primary molars with a mesial step relationship; Class I left and right canine relationship; upper normal midline and lower midline deviation to the right; diastemas present in the upper arch but absent in the lower arch; and overall satisfactory tooth condition.

He was subjected to nine sessions dedicated to encouraging the abandonment of the pacifier and bottle habit. Pacifier-sucking had been eradicated as of the fourth consultation which consisted of orientation and encouragement of the family and play activities with the child, however, the use of the bottle persisted. There was an improvement in the $A O B$ clinical appearance as a result of abandoning the pacifier, however, due to the persistent use of the bottle and the interposition of the tongue, the open bite was not completely corrected. To achieve this, it was necessary to enlist the cooperation of a multidisciplinary team.

Case 3 was the most complex of the cases since, over the course of the clinical consultations, questions were raised by the mother with regard to the child's behavior which could only have been resolved with a comprehensive, multidisciplinary approach involving a psychologist, speech therapist, nutritionist, occupational therapist and social welfare assistant, whose interventions were fundamental in helping to resolve the case. Open bite correction was achieved after these interventions (figure 3).

\section{DISCUSSION}

The cases presented in this study relate to children in the primary dentition phase with persistent use of

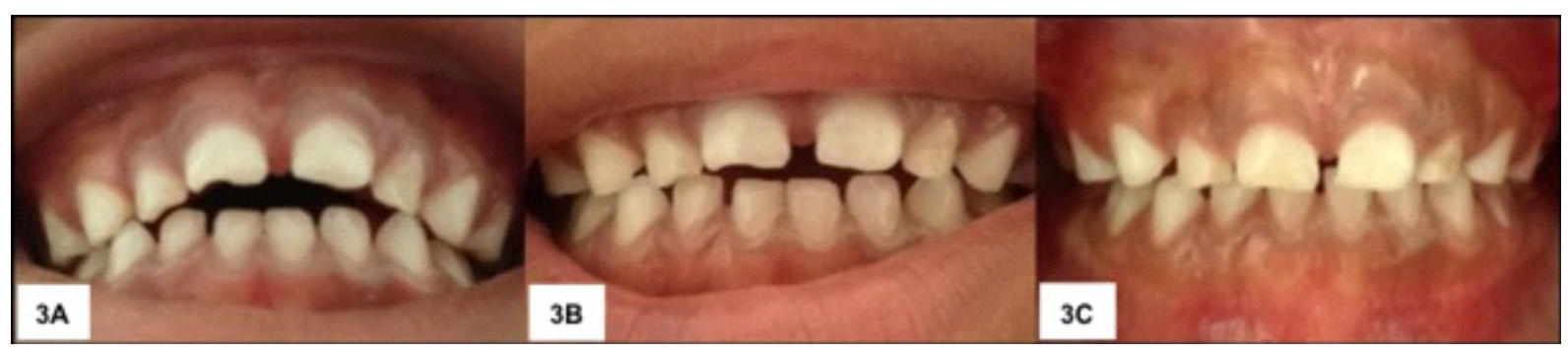

Figure 3. Evolution of the correction of anterior open bite (AOB) in Case 3. A) Initial appearance in a child aged 4 years and 3 months, with pacifier and bottle-sucking habit, with an $A O B$ of $2 \mathrm{~mm}$ and overjet of $4 \mathrm{~mm}$. B) AOB viewed four months after abandoning the pacifier. C) Final evaluation of occlusion nine months after initial evaluation, demonstrating correction of $A O B$ after intervention by a multidisciplinary team. 
pacifiers and with anterior open bite. The children were encouraged to kick the habit using play activities and were monitored for potential spontaneous correction of open bite.

Sucking on a pacifier represents a deleterious habit that can cause changes in the development and growth of the face, affecting the dentition and, when prolonged, can cause more severe disturbances of the stomatognathic system $[2,3,24]$. Consequently, in this study, the parents/ guardians were instructed and educated about the occlusal and myofunctional changes resulting from persisting sucking on a pacifier and, subsequently, the children were encouraged to quit the habit using play activities like the use of children's stories, illustrations and photographs relating to anterior open bite as strategies for cessation of the habit. These methods are consistent with the literature which points to the use of strategies such as meetings and educational programs with parents/guardians and with the children, as important methods for disseminating knowledge, and they help enormously in encouraging the cessation of this deleterious oral habit $[6,14,17,22]$.

Once the children had abandoned the pacifiersucking habit, they were monitored to determine if there might be a spontaneous correction of open bite. In Cases 1 and 2, passive self-correction was observed, subsequent to professional intervention to educate and encourage the cessation of the use of the pacifier and bottle, which corroborates accounts found in the literature which obtained self-correction of this malocclusion in 53.3\% [17] and $70.1 \%$ of cases [18]. It should be emphasized that in Case 2, the lack of lip sealing did not amount to an indication of mouth breathing through obstruction, but rather through habit. The lip sealing evaluation constitutes a clinical parameter for considering if the patient could be a mouth breather [25]

Anterior open bite can be self-corrected in the primary dentition, an occurrence that could be observed in the clinical cases reported. This can happen provided that the sucking habit is nipped in the bud and that the child does not present with other associated risk factors such as abnormal function and posture of the tongue, mouth breathing, heredity, among others, which could negatively impact self-correction of anterior open bite. The involvement of the pediatric dentist is crucial for the family to gain an understanding while the child is still at a tender age, seeing that the literature suggests that the habit of sucking on a pacifier should be eradicated by the age of two [18], or up to three years, in order to cause less damage to the dental occlusion and allow the process of self-correction to proceed more smoothly $[3,6]$. Nevertheless, the use of a pacifier is often prolonged beyond this age, therefore the health professionals and educators need to incentivize the dissemination of information with the aim of alerting and instructing the parents/guardians about the need for their children to abandon deleterious oral habits $[6,14]$. The assistance of a psychologist to supplement the appropriate therapy may be considered as important help for stopping the habit [26].

It is important to stress that anterior open bite is a form of malocclusion of multifactorial etiology so that, in some patients, self-correction does not occur just by removing one factor, as in the case of abandoning the use of the pacifier $[9,27]$. Accordingly, in many situations, a multidisciplinary approach may be important in the evaluation of factors associated with the persistence of the habit and the damage caused by open bite $[4,28]$. When these factors are not correctly diagnosed, treatment failure can ensue with the chance of recurrence [21].

Myofunctional changes such as hypotonicity and interposition of the tongue and mouth breathing were also present in Case 3, thereby making it difficult to achieve self-correction of anterior open bite even once the use of the pacifier and bottle had ceased. These situations need to be worked through using a multidisciplinary approach to reduce the impact and normalize oral functions, as these are essential for achieving self-correction of open bite that originates from the habit of pacifier sucking $[4,28]$. Multidisciplinary involvement in this case required intervention from a psychologist, speech therapist, nutritionist, occupational therapist and social welfare assistant who provided assistance in the Pediatric Dental clinic, to encourage the abandonment of the persistent bottle-sucking habit and the correction of the tonicity and posture of the lingual and labial musculature, fundamental for promoting the correction of anterior open bite. Treatment that focuses on the holistic view of the child from a biological, family and social perspective, permitted a more precise diagnosis with regard to the causes of the anterior open bite and also the best form of treatment, given that the treatment plan depends on the correct diagnosis of the etiology and the malocclusion to be treated [29].

In this study, it was noted that the use of the bottle exerted an important role, just as much as the pacifier, as 
a deleterious oral habit, present in all three cases. Thus, in addition to the positive cooperation and engagement of the parents/guardians, professional stimulus was required so that the children could completely dispense with their use. The parents reported that their children fed normally and therefore were not dependent on the bottle as an exclusive form of nutrition but that, for some reason they did not understand, the child did not accept using a beaker instead of a bottle, although the majority of these parents/ guardians reported that they had made great efforts to do so. Thus, clinically, it was possible to observe that while the bottle continued to be used, even with the total cessation of the use of the pacifier, the anterior open bite persisted, leading us to believe that the bottle is also a significant factor for the persistence of anterior open bite, as discussed in the literature [30].

As has already been described, the involvement of professionals from various areas, in addition to the area of Dentistry, was required. The participants were admitted to the Pediatric Dental clinic where the need for multiprofessional intervention was noted and, accordingly, the appropriate referrals were made. Dealing with the needs of others goes far beyond excellence of technique learned in one's academic training. It is also necessary to know how to perceive from where and why these necessities arise in order to choose the best treatment and this can be realized in a more satisfactory way with the use of multiprofessional intervention. In the present study, the multiprofessional treatment was facilitated because Dentistry is part of the Multiprofessional Healthcare Residency team, with its area of focus being Child and Adolescent Healthcare, which contributed significantly to the discussion and management of the cases. Other studies have also concluded that multiprofessional care is fundamental to the success of the treatment for anterior open bite $[4,26,28,29]$.

In addition to the mechanical and functional removal of the sucking habit, the multidisciplinary approach also succeeds in embracing the emotional context in which the child finds him/herself. Thus, therapeutic treatment for the correction of anterior open bite, besides the dental specialties, can include the joint involvement of Psychology and Speech Therapy [28]. Some cases may also include the participation of specialties from the medical area such as Allergology and Otorhinolaryngology if there is some relation to mouth breathing [15].
Among the psychosocial factors identified, the difficulty of adhering to treatment, the lack of scheduled consultations and the inconstant monitoring of the child with regard to the proposed instruction, may be mentioned. As far as sociocultural factors are concerned, we would highlight the very persistence of the pacifiersucking habit and, even after it has ceased, the persisting, frequent use of the bottle, both encouraged by the family. In terms of biological factors, interference was observed from interposition of the tongue and mouth breathing.

This study posed some limitations due to the small number of participants and, as it was a convenience sample, the results cannot be generalized. Another limitation relates to the fact it is a clinical study, without the use of imaging examinations, so that more accurate assessments involving skeletal factors that might be involved in the etiology of the anterior open bite, could not be performed.

\section{CONCLUSION}

From the moment that the parents/guardians received and understood the professional orientation regarding the deleterious effects that the persistent use of the pacifier can cause, they gave their support to the project and proceeded to encourage the child to relinquish the habit. The play activities used were effective in encouraging the child to stop using the pacifier.

The suspension of the pacifier-sucking habit made self-correction of the anterior open bite possible. The existence of other factors involved in the etiology of this malocclusion, such as the use of bottle feeding, the interposition of the tongue and mouth breathing, can make self-correction of anterior open bite difficult after the pacifier has been relinquished, with multidisciplinary intervention being required to achieve successful treatment.

\section{Collaborators}

GP de BORTOLO participated in the data collection, data analysis and writing the manuscript; LC SARMENTO, APM GOMES and AMM GOMES participated in data analysis and interpretation of results; MCT PACHECO and ECV DADALTO participated in the study design, data analysis, interpretation of results and contributed to the writing of the manuscript. All authors reviewed the text and approved its final version. 


\section{REFERENCES}

1. Antoun TRA, Santos DCL, Flaiban E, Negrete D, Bortolin R, Santos RL. Mordida aberta anterior - uma revisão da literatura. Rev Odontol Univ Cid. 2018;30(2):190-99.

2. Campos MPMS, Valença PAM, Silva GM, Lima MC, Jamelli SR, Góes PSA. Influence of head and linear growth on the development of malocclusion at six years of age: a cohort study. Braz Oral Res. 2018. http://dx.doi.org/10.1590/18073107bor-2018.vol32.0098

3. Carrascoza KC, Possobon RF, Tomita LM, Moraes ABA. Consequences of bottle-feeding to the oral facial development of initially breastfed children. J Pediatr. 2006;82(5):395-97. http://dx.doi.org/10.2223/JPED.1536

4. Chen X, Xia B, Ge L. Effects of breast-feeding duration, bottlefeeding duration and non-nutritive sucking habits on the occlusal characteristics of primary dentition. BMC Pediatrics. 2015;15(46). http://dx.doi.org/10.1186/s12887-015-0364-1

5. Dadalto ECV, Rosa EM. Aspectos culturais para a oferta da chupeta às crianças. Rev Bras Cresc Desenv Humano. 2013; 2(23):231-37.

6. Dadalto ECV, Rosa EM. Fatores associados ao uso de chupeta por lactentes nascidos pré-termo. Rev CEFAC. 2016;18(3):601-12; http://dx.doi.org/10.1590/1982-0216201618319715

7. Durigon M, Palaoro M, Woitchunas FE, Trentin MS. Use of dummy and possible morphological and functional changes in children. SALUSVITA. 2016; 35(3):397-410.

8. Flores-Mir, C. Limited evidence suggests that a history of suboptimal breastfeeding may increase the risk of developing anterior open bite, posterior crossbite, and class ii canine relationship. J Evid Based Dent Pract. 2018;18(1):79-81. http://dx.doi.org/10.1016/j.jebdp.2017.12.004

9. Lopes-Freire GM, Cárdenas ABCC, Deza JEES, Ustrell-Torrent JM, Oliveira LB, Quesada-JR JRB. Exploring the association between feeding habits, non-nutritive sucking habits, and malocclusions in the primary dentition. Prog Orthod. 2015;43(16). http://dx.doi.org/10.1186/s40510-015-0113-x

10. Mendes MLM, Gluszevicz AC, Saldanha MD, Costa VPP, Gabatz RIB, Michelon D. The influence of cultural reproduction on the pacifier sucking habit. Rev Pesq Qualit. 2019;7(13):89-116. http://dx.doi.org/10.33361/RPQ.2019.v.7.n.13.132

11. Nelson AM. A Comprehensive Review of Evidence and Current Recommendations Related to Pacifier Usage. J Pediatric Nurs. 2012;(27): 690-99. http://dx.doi.org/10.1016/j. pedn.2012.01.004

12. Nihi VSC, Maciel SM, Jarrus ME, NIHI FM, Salles CLF, Pascotto RC, Fujimak $M$, et al. Pacifier-sucking habit duration and frequency on occlusal and myofunctional alterations in preschool children. Braz Oral Res. 2015;29(1):1-7.

13. Scarpelli BB, Berger SB, Punhagui MF, Oliveira CAZ, Ferelle A, Oltramari-Navarro PVP. Evaluation of a preventive educational program for malocclusions: 7-year study. Braz Oral Res. 2016;30(1):119-126. http://dx.doi.org/10.1590/18073107BOR-2016

14. Valério $P$, Silva FGS, Santos $C R$, Vasconcelos $M$, Zina $L G$. Aleitamento materno: amar, nutrir e crescer. Implicações clínicas da promoção do aleitamento materno na prática profissional do cirurgião-dentista. Rev Assoc Paul Cir Dent. 2018;72(3):496-502.

15. Wagner $Y$, Heinrich-Weltzien. Occlusal characteristics in 3-year-old children - results of a birth cohort study. BMC Oral Health. 2015;94(15). http://dx.doi.org/10.1186/s12903-0150080-0

16. Góis EGO, Ribeiro-Júnior HC, Vale MPP, Paiva SM, Serra-Negra JMC, Ramos Jorge $\mathrm{ML}$, et al. Influence of Nonnutritive Sucking Habits, Breathing Pattern and Adenoid Size on the Development of Malocclusion. Angle Orthod. 2008;78(4):647-654.

17. Verrastro AP. Avaliação oclusal e miofuncional oral em crianças com dentição decídua completa e mordida aberta anterior antes e após remoção do hábito de sucção de chupeta. São Paulo: Universidade de São Paulo; 2005.

18. Góis EG, Vale P, Paiva SM, Abreu MH, Serra-Negra JM, Pordeus IA. Incidence of malocclusion between primary and mixed dentitions among Brazilian children. A 5-year longitudinal study. Angle Orthod. 2012;82(3):495-500.

19. Pereira TS, Oliveira F, Cardoso MCAF. Pereira TS., Oliveira F., Cardoso MC AF. Association between harmful oral habits and the structures and functions of the stomatognathic system: perception of parents/guardians. CoDAS. 2017; 29(3). http:// dx.doi.org/10.1590/2317-1782/20172015301

20. Fernandes DMZ, Lima MCMP. A visão dos pais e professores sobre a ocorrência de hábitos orais deletérios em um grupo de pré-escolares. Rev CEFAC. 2019;21(2):144-18. http:// dx.doi.org/10.1590/1982-0216/201921214418

21. Arroyo IR, Mattar C, Crepaldi MV, Soares LG, Kawauchi M Y, Peron BG. Tratamento precoce da mordida aberta anterior. Faipe. 2017;7(1):16-24.

22. Muzulan CF, Gonçalves MIR. O lúdico na remoção de hábitos de sucção de dedo e chupeta. J Soc Bras Fonoaudiol. 2011;23(1):66-70.

23. Dadalto, ECV. O mundo mágico da fada da chupeta. Vitória: GM Ed, 2015.

24. Costa CT, Shqair AQ, Azevedo MS, Goettems ML, Bonow MLM, Romano AR. Pacifier use modifies the association between breastfeeding and malocclusion: a cross-sectional study. Braz Oral Res. 2018. http://dx.doi.org/10.1590/18073107bor-2018.vol32.0101

25. Pacheco MCT, Casagrande CF, Teixeira LP, Finck NS, Araújo MTM. Guidelines proposal for clinical recognition of mouth breathing children. Dental Press J Orthod. 2015;20(4):39-44. http://dx.doi.org/10.1590/2176-9451.20.4.039-044.oar

26. Borrie FRP, Bearn DR, Innes NPT, Iheozor-Ejiofor Z. Interventions for the cessation of non-nutritive sucking habits in children. Cochrane Database Syst Rev. 2015 Mar 31;2015(3):CD008694. http://dx.doi.org/10.1002/14651858. CD008694.pub2

27. Maciel CTV, Leite ICG. Etiological aspects of anterior open bite and its implications to the oral functions. Rev Atualiz Cient. 2005;17(3):293-302. 
28. Farias AVM, Vasconcelos MCR, Fontes LBC, Benevides SD. Repercussões das estratégias de retirada dos hábitos orais deletérios de sucção nas crianças do programa de saúde da família em Olinda - PE. Rev CEFAC. 2010;12(6):971-76.

29. Bona AP, Moreira KMS, Tedesco TK, Imparato JCP, Ferreira BD, Reis JB. Multidisciplinary performance to anterior open bite associated with finger sucking: case report. Rev Assoc Paul Cir Dent. 2016;70(1):58-63.
30. Montaldo L, Montaldo P, Cuccaro P, Caramico N, Minervini G. Effects of feeding on non-nutritive sucking habits and implications on occlusion in mixed dentition. Intern J Paediatr Dent. 2011;1(21):68-73.

Received on: 5/6/2020

Final version resubmitted on: 11/9/2020

Approved on: 17/9/2020 